blood flow in each part of the lungs. From this, values of relative underventilation (summed for both lungs) were calculated and plotted against arterial oxygen tension for each patient (fig 3). The extent of the relative underventilation correlated well with the degree of arterial hypoxaemia. A slight refinement of allowing for the age dependence of normal arterial oxygen tension in calculating the degree of hypoxaemia attributable in each patient to the pulmonary embolism further improved this correlation.

In view of the above considerations we postulate that the development of ventilation-perfusion mismatching in regions of non-embolised lung was an important cause of hypoxaeria in our patients. There has been no general agreement about the cause of hypoxaemia in acute pulmonary embolism in man, and evidence has been provided for right to left intrapulmonary shunting 11 and impairment of gas diffusion. ${ }^{12}$ These results are not necessarily incompatible with ours. Localised atelectasis and prolonged breathing of oxygen may produce shunting. We were at pains to exclude these in the present study, whereas one or more of them appears to have been present in most patients in other studies. " 11 ' 2 Furthermore, other mechanisms of hypoxaemia might be operating in massive pulmonary embolism accompanied by appreciable haemodynamic disturbances, which were not detected in our mild cases.

One possible way of exploring the relative roles of mismatching and shunting would be to use $100 \%$ oxygen breathing as a discriminatory test. ${ }^{13}$ Observations of this kind do not appear to have been reported to date and were not possible in the present series because we studied the patients retrospectively.

Finally, some support for our hypothesis may be drawn from animal studies in which pulmonary embolisation with autologous clot $^{1415}$ or gas bubbles ${ }^{16}$ caused hypoxaemia by disturbing ventilation-perfusion ratios in the direction that we postulate.

GHB was in receipt of a Charing Cross Hospital trustees' clinical research fellowship during part of this work.

\section{References}

' Wilson JE, Pierce AK, Johnson RL, et al. Hypoxaemia in pulmonary embolism, a clinical study. F Clin Invest 1971;50:481-91.

McIntyre KM, Sasahara AA. The hemodynamic response to pulmonary embolism in patients without prior cardiopulmonary disease. Am 7 Cardiol 1971 ;28:288-94. Szucs MM, Brooks HL, Grossman W, et al. Diagnostic sensitivity of laboratory findings in acute pulmonary embolism. Ann Intern Med 1971;74:161-6.

Burton GH, Vernon P, Seed WA. An automated quantitative analysis of ventilationperfusion lung scans. I Nucl Med $1984 ; 25: 564-70$.

ernon P, Burton GH, Seed WA. Quantitation of ventilation and perfusion lung scans. Nuclear Medicine Communications 1982;3:107. perfusion lung scans. Clin Sci 1983;64:49P.

perfusion lung scans. Clin $S c i 1983 ; 64: 49 \mathrm{P}$.
Sorbini CA, Grassi V, Solinas E, Muiesan G. Arterial oxygen tension in relation to age in healthy subjects. Respiration $1968 ; 25: 3-13$

DeNardo GL, Goodwin DA, Rowasini R, Dietrich PA. The ventilatory lung scan in the diagnosis of pulmonary embolism. $N$ Engl F Med 1970;282:1334-6. Fazio F, Lavender JP, Steiner RE. $\mathrm{Kr}-81 \mathrm{~m}$ ventilation and $\mathrm{Tc}-99 \mathrm{~m}$ perfusion scans in chest disease: comparison with standard radiographs. American fournal of Roentgenology 1978;130:421-8.

"Dalen JE, Banas JS, Brooks HL, Evans GL, Paraskos JA, Dexter L. Resolution rate of acute pulmonary embolism in man. $N$ Engl $f$ Med 1969;280:1194-9.

D'Alonzo GE, Bower JS, DeHart P, Dentzker DR. The mechanisms of abnormal gas exchange in acute massive pulmonary embolism. Am Rev Respir Dis 1983;

Robin ED, Farkner CE, Bromberg PA, Croteau JR, Travis DM. Alveolar ga exchange in clinical pulmonary embolism. $N$ Engl f Med 1960;262:283-7.

entilating parts of the lung. Acta Physiol Scand 1942;suppl 2:1-92.

thromboembolism in dogs. $\mathcal{F}$ Appl Physiol 1975;39:41-6. antzker DR, Wagner PD, Tornabene VW, Alazraki NP, West JB. Gas exchange after pulmonary thromboembolization in dogs. Circ Res 1978;42:92-103.

${ }^{6}$ Verstappen FTJ, Bernards JA, Kreuzer F. Effects of pulmonary gas embolism on circulation and respiration in the dog. Pfluegers Arch 1977;370:71-5.

(Accepted 27 April 1984)

\title{
Persistent fetal haemoglobin and falsely high glycosylated haemoglobin levels
}

\author{
R B PAISEY, R READ, R PALMER, M HARTOG
}

\begin{abstract}
Some of the routine methods of measuring glycosylated haemoglobin depend on its difference in charge from haemoglobin $A$ and do not distinguish between glycosylated haemoglobin and fetal haemoglobin. Two insulin dependent diabetics showed persistent discrepancies between their capillary blood glucose values and their glycosylated haemoglobin values measured by agar gel electrophoresis: the blood values were normal but the glycosylated haemoglobin values were raised. In one patient increases in insulin dose in response to the glycosylated haemoglobin results repeatedly produced hypoglycaemia. Both patients were found to have higher than normal concentrations of fetal haemoglobin; and when measured by the thiobarbituric acid reaction their glycosylated haemoglobin levels were almost normal.
\end{abstract}

This problem may be avoided by using a method that distinguishes between fetal and glycosylated haemoglobin or by testing glycosylation of hair or serum albumin if discrepancies arise. This is particularly important during pregnancy, when some women have an increase in fetal haemoglobin.

\section{Introduction}

Glycosylated haemoglobin is widely used as a measure of diabetic control in insulin treated patients, often in conjunction with home blood glucose monitoring. Some of the methods routinely used for measuring glycosylated haemoglobin depend on its separation from haemoglobin A by a difference in charge-for example, column techniques and agar gel electrophoresis. With all of these methods fetal haemoglobin $(\mathrm{HbF})$ will migrate with glycosylated haemoglobin and, if present, give a falsely high reading.'

\section{Case 1}

A 24 year old research assistant had been diabetic for 15 years. She adjusted her dose of twice daily quick and intermediate acting insulins according to home blood glucose concentrations measured by BM $20-800$ strips and confirmed by filter paper capillary blood glucose measurement. These consistently showed normal or near 
normal results. In contrast, her glycosylated haemoglobin concentrations measured by agar gel electrophoresis were always between $13 \%$ and $16 \%$ (normal range $5 \cdot 5-7.5 \%$ ), indicating poor diabetic control. Increases in her insulin dose and dietary restrictions repeatedly led to troublesome hypoglycaemia.

Because of this disparity, fetal haemoglobin estimation was performed, ${ }^{2}$ which showed $2 \cdot 7 \% \mathrm{HbF}$ (normal less than $0.6^{\circ}{ }_{01}$ ). Simultaneous measurement of glycosylated haemoglobin by agar gel electrophoresis and by the thiobarbituric acid reaction gave results of $14.5 \%$ and $9.0 \%$ respectively. As a further independent assessment avoided by measuring glycosylated haemoglobin by a chemical method, such as the thiobarbituric acid reaction; by the more precise electrophoretic technique of isoelectric focusing; or by affinity chromatography. Alternatively, in cases in which discrepancies arise between glycosylated haemoglobin and carefully documented home blood glucose analyses, glycosylation of another protein or tissue such as serum albumin or hair could be used. The issue is of particular importance in the management of diabetic women during pregnancy as maternal

Capillary blood glucose, hair, and haemoglobin glycosylation studies in two diabetic patients. Figures in parentheses after thiobarbituric acid incubation result are expected ". glycosylated $\mathrm{Hb}$ from the figure

\begin{tabular}{|c|c|c|c|c|c|c|}
\hline \multirow[b]{2}{*}{ Case No } & \multirow[b]{2}{*}{ Date } & \multirow{2}{*}{$\begin{array}{c}\text { Mean } \\
\text { capillary blood glucose } \\
(\mathrm{mmol} / 1)\end{array}$} & \multirow{2}{*}{$\begin{array}{c}\text { Hair glycosylation } \\
\text { ( } \mu \mathrm{mol} \text { fructosamine } / 100 \mathrm{mg} \text { ) }\end{array}$} & \multicolumn{3}{|c|}{ Glycosylated haemoglobin } \\
\hline & & & & Agar gel $\left({ }^{\circ}{ }_{10}\right)$ & $\begin{array}{l}\text { Thiobarbituric acid reaction } \\
\text { ( } \mu \mathrm{mol} \text { fructosamine } / 100 \mathrm{mg} \text { ) }\end{array}$ & $\% \mathrm{HbF}$ \\
\hline 1 & Jan 1984 & $\begin{array}{l}7 \cdot 2 \\
8 \cdot 1\end{array}$ & 0.055 & 14.5 & $0 \cdot 27\left(9 \cdot 0^{\prime \prime \prime}\right)$ & $2 \cdot 7$ \\
\hline 2 & March 1984 & $11 \cdot 2$ & 0.09 & $\begin{array}{l}13.3 \\
18\end{array}$ & $0.41(12.5 \%)$ & 50 \\
\hline 2 & May 1984 & $10 \cdot 1$ & & $16 \cdot 4$ & $0.39\left(11 \cdot 6^{110}{ }_{0}\right)$ & $1 \cdot 6$ \\
\hline \multicolumn{2}{|c|}{ Normal ranges } & 6.0 & $0.032-0.070$ & $5 \cdot 5-7 \cdot 5$ & $0 \cdot 13-0 \cdot 25$ & 0.6 \\
\hline
\end{tabular}

Conversion: SI to traditional units-Blood glucose: $1 \mathrm{mmol} / 1=18 \mathrm{mg} / 100 \mathrm{ml}$

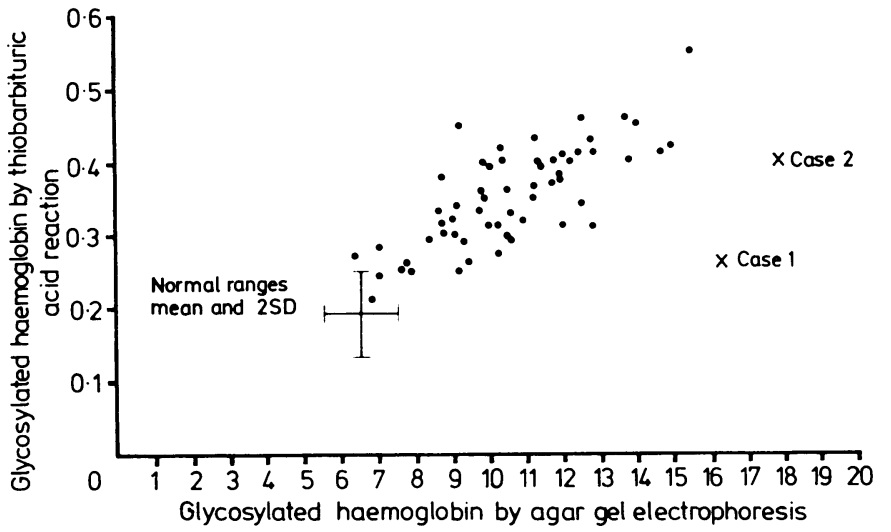

Relation between glycosylated haemoglobin measured by agar gel electrophoresis and the thiobarbituric acid incubation in 58 patients, with results from cases 1 and 2 . $r=0.76 ; \mathrm{p}<0.01$.

of chronic hyperglycaemia, glycosylation of scalp hair was assayed and found to be within the normal range at $0.055 \mu \mathrm{mol}$ fructosamine/ $100 \mathrm{mg}$ (normal range $0 \cdot 035-0 \cdot 07$ ).

\section{Case 2}

The first patient's mother, aged 48, had been diabetic for 27 years and also had coeliac disease. Her glycosylated haemoglobin values were consistently grossly raised at $16-18^{\circ}$, , as compared with filter paper blood glucose concentrations of 10-11 mmol/l $(180-198 \mathrm{mg} / 100 \mathrm{ml})$. Her fetal haemoglobin level was $5^{\circ}{ }^{\circ}$, and simultaneous measurements of glycosylated haemoglobin by agar gel electrophoresis and by the thiobarbituric acid reaction showed values of $18^{\circ}{ }_{\circ}^{\circ}$ and $12.5^{\circ}{ }^{\prime}$, respectively.

The table shows these results in full, repeated on two occasions, and the figure the normal relation between glycosylated $\mathrm{Hb}$ concentrations measured by the two methods.

\section{Discussion}

Persistent fetal haemoglobin is fourd as an isolated anomaly in $1 \%$ of white patients ${ }^{4}$ and is not in itself clinically important. In our two patients, however, inappropriate advice to increase their insulin doses was given because of the overestimation of glycosylated haemoglobin by a method which included fetal haemoglobin in the measurement. This difficulty can be fetal haemoglobin concentrations rise from the 10th week in a small proportion of women..$^{5}$

Furthermore, some patients with more serious inherited genetic variants of haemoglobin synthesis such as thalassaemias and sickle cell disease have increased levels of $\mathrm{HbF}$.

\section{References \\ 'Hall PM, Cawdell GM, Cook JGH, Gould BJ. Measurement of glycosylated haemoglobins and glycosylated plasma proteins in maternal and cord blood using an affinity chromatography method. Diabetologia 1983;25:477-81. \\ 'Singer K, Chernoff AJ, Singer L. Studies on abnormal haemoglobins. I. Their demonstration in sickle cell anemia and other hematologic disorders by means of alkali denaturation. Blood $1951 ; 6: 413-20$. \\ ${ }^{3}$ Paisey RB, Clamp JR, Kent MJC, Light ND, Hopton M, Hartog M. Glyco- sylation of hair: possible measure of chronic hyperglycaemia. $\mathrm{Br}$ Med $\mathrm{f} 1984$; 288:669-71. \\ - Weatherall DJ, Cartner R, Clegg JB, Wood WG, Macrae JA, Mackenzie A. A form of hereditary persistence of fetal haemoglobin characterised by uneven cellular distribution of haemoglobin 1 and the production \\ and $\mathrm{A}_{2}$ hemolobins. III. Feta \\ haemoglobin changes in the circulation of pregnant women. Blood 1955;10 haemoglot}

(Accepted 26 fune 1984)

\section{ONE HUNDRED YEARS AGO}

The native press have (says the India Medical Gazette) lately been discussing a subject of immense practical importance. With reference to the death of the Honourable Rai Cristo Das Pal, at the comparatively early age of 45 , the question arose, Why do all the leaders of native thought in India die young? The majority of the papers answered it by pointing to the unhealthy conditions under which an intelligent Hindu is born and is obliged to work. His mother-probably his father also-was a mere child at his birth; he himself marries as a mere child, and at twenty-one or twenty-two has the cares of a large and increasing family upon him. He has no breathing-time, or happy independence in early manhood, like the youth of Europe. $\mathrm{He}$ is forced by necessity to be precociously old; and in what we should call early middle life he finds himself prematurely worn out and exhausted. Thus the burden of the complaint is the custom of child-marriage. Certain educated Hindu gentlemen are calling upon the Government to legislate against these enforced child-marriages; but these are matters in which the Government cannot interfere. Such social reform must be brought about within the society itself; and, although its accomplishment is unlikely to be speedy, the educated part of the community should be encouraged to persevere in their crusade against ignorance and prejudice, in the hope of ultimate success. (British Medical fournal 1884 ;ii:872.) 